\title{
5.9 Реалізація перетворень в умовах антикризового управління аграрними підприємствами
}

У ситуації кризи більшість власників та менеджерів думають лише про те, як елементарно вижити. В складні часи їм це здається єдино можливою стратегією. Необхідно зазначити, що більшість керівників навіть не змогли вести бізнес в інших, жорсткіших умовах. Вони виявилися не лише не готові до кризи, а й не реагували на неї, допоки не впали обсяги продажу, контрагенти перестали виконувати свої зобов'язання, а гроші не зависали на банківських рахунках.

В різних літературних джерелах науковці виділяють багато значень терміну «криза», зокрема, що фінансова криза - це глибокий розлад державної фінансової системи, що проявляється у нестабільності і падінні валютного курсу національної грошової одиниці, інфляції, нестійкістю курсів цінних паперів, що проявляється в різкій невідповідності доходів бюджету їх видаткам; періодичне перевиробництво товарів, що призводить до різкого загострення всіх суперечностей економіки країни: скорочення виробництва, розладу кредитних $\mathrm{i}$ грошових відносин, банкрутства фірм, масового безробіття [233].

Виникнення кризи на підприємствах аграрного сектору обумовлено об'єктивною особливістю умов його функціонування: невизначеністю зовнішнього середовища і нестабільністю його внутрішнього середовища, а також суб'єктивною стороною: особливістю сприйняття i переробки менеджментом підприємства інформації про зміни, що відбуваються.

Кожне підприємство в тій чи іншій мірі у своїй господарській діяльності відчуває на собі кризові явища, економічні та фінансові проблеми, що нерідко призводять до банкрутства.

Криза на агровиробничих підприємствах - це загострення протиріч, що загрожує його життєстійкості. Агропідприємство вважається кризовим, як і всякий виробничий процес, коли воно перестає отримувати прибуток або коли отриманий прибуток не забезпечує в якості джерела фінансових ресурсів можливість покриття поточних витрат і необхідних потреб [234]. Криза може бути обумовлена браком власного капіталу, що призводить до росту боргових 
зобов'язань, некомпетентністю керівництва, впливом несприятливих зовнішніх факторів. Протиріччя між виробництвом і споживанням - головна, але не єдина причина економічних криз.

Подолання кризи - це побудована система управління, націлена на виявлення ознак кризових явищ та створення відповідних передумов для їх своєчасного подолання, забезпечення виживання і відновлення життєздатності сільгосппідприємства i недопущення банкрутства. Система управління підприємством припускає принципову зміну функцій учасників бізнес-процесів, механізмів їх взаємодії, а так само організації матеріальних, фінансових, інформаційних та інших потоків [235].

Антикризове управління сільгосппідприємством враховує галузеві особливості аграрного сектору. Вибір правильної стратегії антикризового управління дає можливість вчасно розпізнати кризову ситуацію i, з огляду на особливість, знизити гостроту. Антикризове управління в умовах зростаючої динамічності підприємницького аграрного середовища вимагає перебудови традиційних поглядів на стратегічне планування в сільгосппідприємстві. Застосування періодичного стратегічного планування дозволяє здійснювати перехід від виконання кризового плану до реалізації актуалізованого стратегічного курсу. Незалежно від причин виникнення і розвитку типів кризи підприємств сільського господарства, існує ряд принципів стратегії виходу 3 кризи, які виробляються на основі досліджень і вивчення досвіду антикризового управління [236].

1. Принцип адаптивності стратегії, управління будується на принципах системного та ситуаційного підходу.

2. Принцип концентрації зусиль на напрямках основної діяльності сільгосппідприємства, які дають основний внесок в кінцевий результат.

3. Принцип диференційованого підходу до стратегії антикризового управління, виходячи з виду кризи, в якому знаходиться аграрне підприємство.

4. Принцип відповідності масштабу i швидкості змін всередині сільгосппідприємства. 
Iз зазначеного вище випливає, що основними завданнями антикризового управління в сільськогосподарських підприємствах є: зміна функціонування господарських механізмів; трансформація критеріїв прийняття управлінських рішень; розробка і реалізація стратегії і тактики управління в нових умовах; активне використання нових можливостей управління; застосування всіх легальних методів господарського маневрування [237].

Саме чітке визначення процесу антикризового управління дозволить не лише своєчасно й ефективно виявити кризи, мінімізувати їх негативні наслідки, але й попередити виникнення кризових явищ у майбутньому. 3 метою забезпечення ефективної протидії кризовим явищам процес антикризового управління необхідно здійснювати поетапно: 1-й етап - створення спеціалізованої робочої групи (антикризової команди); 2-й етап - проведення діагностики та оцінка параметрів кризи; 3-й етап - визначення мети і завдань антикризового управління, пошук способів виходу підприємства 3 кризи, визначення необхідних ресурсів, перевірка можливості досягнення поставлених цілей; 4-й етап - оцінка ресурсного потенціалу та часових обмежень антикризового управління; 5-й етап - розробка антикризової програми; 6-й етап - створення системи реалізації антикризової програми виходу підприємства 3 кризової ситуації; 7-й етап - організація впровадження антикризової програми та контроль за її виконанням; 8-й етап - аналіз доцільності подальшого проведення заходів щодо виходу підприємства 3 кризової ситуації; 9-й етап - розробка заходів щодо прогнозування і профілактики майбутніх кризових ситуацій [239].

Як інструмент в процесі антикризового управління в сільськогосподарських організаціях використовується найбільш радикальний спосіб перетворень реструктурування сільгосппідприємства. Під реструктурування в аграрному секторі розуміються фундаментальні комплексні зміни, в основі яких лежить трансформація структури бізнесу i способу функціонування сільгосппідприємства, що охоплює практично всі аспекти його діяльності, кінцевою метою якої $\epsilon$ підвищення ефективної роботи i конкурентоспроможності, збільшення прибутковості. Реструктурування, що 
припускає оновлення всіх сфер діяльності, необхідно аграрним виробникам для адаптації в нових умовах господарювання.

Існуючі розробки з описом окремих варіантів реструктурування на основі створення системи бізнес-одиниць і на основі створення малих підприємств на базі великих через процедуру поділу та виділення недостатньо ефективних $\mathrm{i}$ вимагають концентрації зусиль на всіх етапах процесу реструктурування. В якості практичного засобу, що сприяє підвищенню ефективності перетворення структури сільгосппідприємства, проведеного в рамках стратегічного реструктурування, розроблена комплексна технологія, що включає п'ять елементів і представляє собою процедуру вибору стратегії, адаптації структурних параметрів, планування та реалізації структурних перетворень в умовах антикризового управління в сільськогосподарських підприємствах.

Перший етап - аналіз причин кризи сільгосппідприємства і оцінка можливості реструктурування. Дослідження внутрішніх і зовнішніх причин кризи, встановлення сильних і слабких сторін сільгосппідприємства. Аналіз проводиться за напрямками структури макро- і мікроумов, які характеризують зовнішні причини кризи та ймовірні загрози [240].

Другий етап - це визначення цілей і стратегічної концепції перетворень. Розробка стратегічного бачення і місії в сільськогосподарських підприємствах, встановлення цілей переводить стратегічне бачення його розвитку в конкретні завдання, пов'язані з сільгоспвиробництвом і результатами його діяльності. До результатів цього етапу відносяться - більш швидке зростання доходів, збільшення прибутку на вкладений капітал, визнання міцного фінансового становища сільгосппідприємства; стратегічні цілі - більш високе і надійне становище в аграрній галузі, зниження витрат сільськогосподарського виробництва, підвищення якості сільгосппродукції.

Третій етап - визначення варіантів структурної перебудови і вибір організаційної стратегії сільгосппідприємства. Критерієм вибору стратегії перетворень сільгосппідприємства є вартісний розрив між вартістю, якою володіє підприємство сільського господарства в даний час, потенційної $\mathrm{i}$ 
вартістю його після реструктуризації [241]. Вартісний розрив, тобто межа між поточною вартістю сільгосппідприємства при існуючих умовах і поточною вартістю нового сільгосппідприємства після реструктуризації, являє собою чисту поточну вартість ефекту реструктуризації.

Четвертий етап передбачає координацію структурних параметрів. Після визначення варіанта організаційної стратегії і встановлення стратегічних господарських регіонів для сільгосппідприємства необхідна координація його структурних параметрів. Найважливішими структурними параметрами сільгосппідприємства є стратегічні види бізнесу, організаційно-правова форма i загальна організація.

П'ятий етап - це планування і реалізація нових структур. Проблематику цього етапу становить часовий графік змін, так як потрібно поступовий підхід.

Особливість такої програми реструктурування сільгосппідприємства є те, що за умови іiі повного здійснення вона дає шанс, навіть якщо і були допущені помилки при виробленні стратегії. Керуючись методологічними принципами системного підходу до реструктуризації, наприклад, принципом інтеграції, використовують наступні моделі:

1. Поділ підприємств аграрного виробництва.

2. Створення спільних підприємств сільського господарства.

3. Створення на базі сільгосппідприємства асоціації фермерських господарств.

4. Створення на базі сільськогосподарського підприємства особистих підсобних господарств (ОПХ).

Застосування цих моделей здійснювалося на підставі результатів аналізу фінансового стану суб'єктів аграрного сектору. Видно, що суть моделі поділу підприємства полягає в тому, що існуюче підприємство ділиться на два і більше самостійних юридичних осіб, які стають його правонаступниками та особливість цього варіанту - одні новостворені підприємства взяли собі тільки ліквідне, а інші - все невикористане майно. У даній моделі кожне новостворене підприємство бере на себе борги пропорційно частці переданого майна. 
Розглядаючи суть другої моделі - створення нового підприємства на базі ліквідної частини активів старого сільгосппідприємства. Модель реалізовувалася за кількома варіантами:

а) суб'єкт створено за участю сторонніх підприємств при наявності інших, які бажали створити спільне підприємство;

б) суб'єкт створено за участю сторонніх підприємств і працівників господарства, готових вкласти кошти в розвиток спільного підприємства;

в) підприємство створено за участю працівників господарства, в разі відсутності підприємства - інвестора і на базі земельної власності громадян господарства. Створення самостійних фермерських господарств на базі сільськогосподарського підприємства, які потім об'єдналися в асоціацію фермерських господарств, основа третин моделі реформування. Ця модель більш ефективна, як визначилося, для підприємств 3 великою кредиторською заборгованістю і низьким виробничим потенціалом, що дало шанс збереження виробництва і вихід на беззбитковий рівень господарювання. Об'єднання особистих підсобних господарств має свої відмінності, метою якого $є$ самозабезпечення учасників особистих підсобних господарств та прилеглих населених пунктів продукцією сільського господарства. Важкий фінансовий стан можливо подолати, якщо створити на базі ОПГ нові комерційні сільськогосппідприємства.

Таким чином, концепція антикризового управління виходить 3 того, що вирішальними для відновлення сільськогосподарського виробництва доведення його до допустимого в сучасній економіці світової спільноти рівня $є$ дві компоненти: аграрна політика держави та ефективний менеджмент в самих сільськогосподарських підприємствах.

Система антикризового регулювання включає основні напрями забезпечення сталого (безкризового) розвитку сільськогосподарських підприємств, це: формування багатоукладного аграрного виробництва; формування ефективної аграрної політики (ціноутворення, кредитування, антимонопольна політика, податкова політика, страхування і т. п.); захист 
інтересів вітчизняного товаровиробника; формування кадрового потенціалу; розвиток науки і здійснення наукової діяльності; розвиток соціальної сфери села; реформування земельних відносин; формування i функціонування ринку сільськогосподарської продукції, сировини і продовольства [242].

Отже, можна зробити висновок, що активізація процесів банкрутства в сільському господарстві призводить до зменшення забезпеченості засобами виробництва сільськогосподарських товаровиробників і деградації галузі. У зв'язку з цим нагальною потребою $є$ запобігання або подолання неспроможності аграрних підприємств при наявності такої можливості. Тому необхідно здійснити глибоку і всебічну діагностику кризових явищ, оцінити їх масштаби, виявити можливість запобігання неспроможності підприємств через реалізацію перетворень в умовах антикризового управління ними. 